\title{
Energy balance of mussels Mytilus galloprovincialis: the effect of length and age
}

\author{
Alejandro Pérez Camacho ${ }^{1, *}$, Uxio Labarta ${ }^{2}$, Enrique Navarro ${ }^{3}$ \\ ${ }^{1}$ Instituto Español de Oceanografía, Centro Costero, Aptdo. 130, 15001 La Coruña, Spain \\ ${ }^{2} \mathrm{CSIC}$, Instituto de Investigaciones Marinas, c/Eduardo Cabello 6, 36208 Vigo, Spain \\ ${ }^{3}$ Dpto de Biología Animal y Genética, Universidad del País Vasco. Aptdo. 644, 48080 Bilbao, Spain
}

\begin{abstract}
Clearance and ingestion rates, absorption efficiencies and respiration rates were measured in mussels Mytilus galloprovincialis Lmk of different lengths (53 to $89 \mathrm{~mm}$ ) and age (10 to $24 \mathrm{mo}$ ) from cultivation rafts in the Ría de Arosa (Galicia, Spain). The experiments were carried out either in the laboratory, using monoalgal food (Isochrysis galbana) with an organic content of $91 \%$, or under natural conditions of food availability in cultivation rafts with seston, the organic content of which ranged from 33 to $69 \%$. Food concentrations ranged from 0.57 to $1.00 \mathrm{mg} \mathrm{l}^{-1}$ of total particulate matter (TPM), a load which is below the threshold for the production of pseudofaeces in Mytilus. These experiments proved that the ingestion rate ( $\mathrm{lR}=\mathrm{mg} \mathrm{TPM} \mathrm{h}^{-1}$ ) of food increases with the size of the mussel (measured as $g$ of soft-tissue dry weight [DW]) according to the power equation $I R=12.661 \mathrm{DW}^{0.619}$, this model accounting for over $90 \%$ of the variance of the $\mathrm{IR}$. Behavioural patterns that tended to maintain constant IR regardless of the density of the food were observed. Absorption efficiency (AE) is positively related to the organic content (OC) of the food according to the following hyperbolic equation: $\mathrm{AE}=$ $1.015-0.163(1 / \mathrm{OC})(\mathrm{r}=0.940)$. AE is independent of mussel size for most of the size range used in this study, but there is a critical length around $85 \mathrm{~mm}$, above which there is a noticeable decrease of AE. Metabolic expenditure, measured in terms of oxygen consumption standarized per unit of dry weight of flesh, tends to increase with the age of the mussel. The results obtained led to the conclusion that physiological traits such as the regulation of ingestion or differences in AE between groups do not explain the differences in growth between mussels of the same age. These differences must therefore be due to the limited food and space available as a result of the large numbers of mussels on the cultivation rafts and the agglomeration of mussels on the cultivation ropes.
\end{abstract}

KEY WORDS: Mytilus · Ingestion rate - Respiration · Absorption efficiency · Food quality

\section{INTRODUCTION}

Unlike mussels from natural populations on intertidal rocks, which exhibit a certain regularity of length for each age group, mussels cultivated on rafts are strikingly different in length, although at the start of the cultivation, all the mussels on a rope are normally of the same age and origin and of very similar length.

The cultivation rafts, upon which over 10000 million mussels can be found on the NW Spanish coast alone, are responsible for the role of the mussel as a key species in the ecosystem of the 'rías' (Tenore \& González 1976).

•E-mail: alejandro.perez@co.ieo.es
The growth of mussels depends on environmental factors, particularly the amount of food ingested and its quality, which strongly determine the efficiency of food assimilation. The filtering activity of bivalves tends to decrease as the food concentration in the water increases, thus regulating the amount of food ingested and maintaining the number of particles filtered in a given period of time relatively constant (Winter 1973, 1978, Foster-Smith 1975, Griffiths \& King 1979, Widdows et al. 1979, Riisgård \& Randløv 1981).

On the other hand, filtering activity, and hence the amount of food ingested, increases as the mussel grows according to an allometric function with $b<1$. In consequence, the daily ration ingested, expressed as \% of dry weight of flesh, decreases with increasing size of the mussels (Winter 1978, Navarro \& Winter 1982). 
Absorption efficiency (AE) varies inversely with the density of suspended food and hence the ingestion rate (Widdows \& Bayne 1971, Thompson \& Bayne 1972, 1974, Griffiths \& King 1979, Griffiths 1980, Navarro \& Winter 1982, Bayne et al. 1989). Although some authors have reported that $\mathrm{AE}$ is also influenced by body size (Bayne et al. 1976), most consider AE to be independent of this variable (Vahl 1973, Thompson \& Bayne 1974, Widdows 1978, Navarro \& Winter 1982).

Given these considerations, how can we explain differences in size between mussels of the same age or differences in age between mussels of the same size? It is clear that for mussels maintained under identical conditions in which $\mathrm{AE}$ is size independent, differences in length between specimens of the same age should be expected to be due to differences in the rate of food uptake. This could be the consequence of limitations of food and space (see Fréchette \& Lefaivre 1990) that arise from the high density of mussels in the culture system. However, differences in growth rate could also be attributed to differences in feeding rate and/or AE that would have enabled some mussels to grow bigger in the same time span. The existence of such fast- and slow-growing groups of mussels could then be tested by comparing feeding behaviour of specimens of the same size and different age under common feeding conditions.

While size effects on several aspects of physiology of mussels have been extensively reported, we are not aware of any other study in which age effects have also been considered. In the present study we aimed to establish the influence of age and length on physiological variables of the mussels, and to determine to what extent differences in growth can be attributed to variations in feeding rate or $A E$, or whether they can be explained by variations in the amount of food available due to the agglomeration of mussels on the cultivation ropes (comparable to the aggregation of mussels in natural populations on intertidal rocks), which cannot be compensated for by changes in the clearance rate.

\section{MATERIAL AND METHODS}

Measurements. Total dry matter and organic matter: Samples of water and faeces from each mussel were filtered on pre-ashed GF/C filters and rinsed with isotonic ammonium formate. Total dry particulate matter (TPM) was computed from the increase in weight after the filters were dried to a constant weight at $110^{\circ} \mathrm{C}$. Particulate organic matter (POM) corresponded to the weight lost after ignition to constant weight at $450^{\circ} \mathrm{C}$ in a muffle furnace. The weights of TPM and POM were measured in $\mu \mathrm{g}$. Food quality was expressed in terms of its organic content $(O C)$ by weight (OC $=$ POM/ TPM). Once these measurements were made, soft tissues from each mussel were excised, dried at $100^{\circ} \mathrm{C}$ and ashed at $450^{\circ} \mathrm{C}$ to determine dry weight (DW) and the weight of organic matter (OW) of the soft tissues. The weight of the valves (VW) was also determined. The weights of DW, OW and VW were measured in mg. A condition index (CI) was calculated as follows (Pérez Camacho et al. 1997):

$$
\mathrm{CI}=100(\mathrm{DW} / \mathrm{VW})
$$

Clearance and ingestion rates: In Expt 1, which was performed in the laboratory, mussels were acclimatized for $1 \mathrm{wk}$ under experimental conditions before measurements began. Clearance rate (CR) was determined in triplicate for each of the 15 mussels used in the experiment (5 of each length), using individual $300 \mathrm{ml}$ metacrylate containers with running seawater $\left(5 \mathrm{l} \mathrm{h}^{-1}\right.$ ) and a concentration of 50000 cells ml ${ }^{-1}$ of Isochrysis galbana equivalent to $1.1 \mathrm{mg} \mathrm{l}^{-1}$ of TPM with an organic content of $91.31 \%$. Containers without mussels were used to calculate any possible sedimentation of phytoplankton, which proved to be negligible. Flow was controlled with 12 -channel variable-flow ISMATEC peristaltic pumps. The following equation was used to calculate the CR:

$$
\mathrm{CR}=f\left[\left(C_{\mathrm{i}}-C_{\mathrm{e}}\right) / C_{\mathrm{e}}\right]
$$

where $C_{\mathrm{i}}$ and $C_{\mathrm{e}}$ represent the concentration of $I$.gaI= bana (cells $\mathrm{l}^{-1}$ ) in the inflow and outflow, respectively, and $f$ is the flow measured in $1 \mathrm{~h}^{-1}$.

The ingestion rate (IR) (mg TPM h $\mathrm{h}^{-1}$ ) was determined using the following equation:

$$
\mathrm{IR}=\mathrm{CR} \times \mathrm{TPM}
$$

where TPM corresponds to the concentration of Isochrysis galbana (in $\mathrm{mg} \mathrm{l}^{-1}$ ). The IR per gram of softtissue DW of the mussels, or mass-specific IR $\left(\operatorname{IR}_{s}\right)$, was also determined.

In the experiments performed in situ on the cultivation rafts (Expts 2 and 3), the measurements were performed on mussels of the same origin cultivated on ropes at a depth of $6 \mathrm{~m}$. The mussels were sorted according to their lengths, their byssus carefully cut and epibionts removed, after which they were placed in mesh bags which were suspended from the raft at a depth of $6 \mathrm{~m}$ for $24 \mathrm{~h}$. Subsequently 18 mussels of each size-group were transferred to individual compartments in feeding tanks, which received a flow of 901 of seawater per hour from a submersible pump situated at a depth of $6 \mathrm{~m}$ in the same place where the mesh bags had been suspended. Samples of seawater for analysis were taken at half-hourly intervals, and the faeces every $2 \mathrm{~h}$, using the methods described by Navarro et al. (1991) and Iglesias et al. (1996). In this 
case the IR was calculated indirectly from the egestion and the inorganic content of the seston (Navarro et al. 1991, Iglesias et al. 1996) according to the following equation:

$$
\mathrm{IR}=\mathrm{ER}(\mathrm{FIC} / \mathrm{SIC})
$$

where ER is the egestion rate, measured in $\mathrm{mg} \mathrm{DW} \mathrm{h}^{-1}$ of faeces, FIC is the fecal inorganic matter content (\%) and SIC is the inorganic matter content of the seston. $\mathrm{CR}$ was then computed by the following expression:

$$
\mathrm{CR}=\mathrm{IR} / \mathrm{TPM}
$$

Absorption efficiency: AE was calculated according to Conover (1966). Absorption rates $(A)$ were estimated as the difference between organic ingestion rates (OIR) and organic egestion rates. Absorption efficiencies (AE) corresponded to the ratio A/OIR.

Oxygen consumption rate: Oxygen consumption rate $\left(\mathrm{VO}_{2}, \mathrm{mg} \mathrm{O}_{2} \mathrm{~h}^{-1}\right)$ and mass-specific $\mathrm{VO}_{2}\left(\mathrm{VO}_{\mathrm{s}}\right)$ were estimated only for Expts 2 and 3 in the same mussels used to estimate the $\mathrm{CR}$. Measurements were taken at half-hourly intervals, using YSI electrodes in $400 \mathrm{ml}$ glass chambers maintained at the environmental temperature with flowing water pumped from the sea. Measurements were concluded before concentration of oxygen in the chambers attained $50 \%$ of the initial concentration.

Experimental design. The experiments were carried out with mussels from the experimental cultures in the Ría de Arosa (Galicia, Spain). All the mussels shared the same origin (spat gathered from rocks on the Island of Sálvora), and were of similar age and size at the start of cultivation. These mussels remained attached to ropes suspended from a raft for between 6 and 18 mo before the experiments began. Three different experiments were performed, 2 of which were intended to determine the influence of size on physiological variables, comparing results obtained in the laboratory with monoalgal food to those obtained on the raft with natural food, whilst the third was designed to study the independent effects of size and age of mussels on the same physiological variables.

Expt 1: This experiment was performed in the laboratory, using Isochrysis galbana as food, with an organic content of $91 \%$, dosed at a TPM concentration of $1.010 \mathrm{mg}$ $\mathrm{l}^{-1}$. Three groups of 5 mussels each were used, measuring between 60 and $63 \mathrm{~mm}$ (average length: $61.6 \pm 0.9 \mathrm{~mm}$ ), 72 and $75 \mathrm{~mm}$ (average length: $73 \pm 1.2 \mathrm{~mm}$ ), and 87 and $90 \mathrm{~mm}$ (average length: $88.9 \pm$ $1.2 \mathrm{~mm}$ ), respectively (means \pm standard error). At the time of the experiment the approximate age of these mussels was $24 \mathrm{mo}$.
Expt 2: This experiment took place on the cultivation raft, using natural food with an organic content of $69 \%$, at a TPM concentration of $0.568 \mathrm{mg} \mathrm{l}^{-1}$. Mussels used in this experiment were of the same origin as those used in Expt 1, were of the same age $(24 \mathrm{mo})$, and were divided into 3 groups of 18 mussels each, with lengths ranging from 56 to 66,71 to 77 and 85 to $92 \mathrm{~mm}$ (average lengths: $60.1 \pm 3.4,73.9 \pm 2.8$ and $88.5 \pm$ $2.6 \mathrm{~mm}$, respectively).

Expt 3: This experiment was carried out under the same natural conditions as Expt 2, but the organic content of seston was $33 \%$ and TPM concentration was $1.007 \mathrm{mg} \mathrm{l}^{-1}$. Mussels belonging to 2 age groups of 10 (juvenile) and 22 (old) mo were subsequently divided each into 2 size-groups. Groups of 'old mussels' had average lengths of $55.7 \pm 1.0$ and $77.9 \pm 0.8 \mathrm{~mm}$, and groups of 'juvenile mussels' had average lengths of $53.85 \pm 0.83$ and $79.42 \pm 0.56 \mathrm{~mm}$. Thus, measurements of Expt 3 were performed on 4 groups of mussels in which age and size varied independently.

Statistical methods. All statistical procedures were performed with STATGRAPHICS software. The differences between means for the variables studied were compared by means of analysis of variance (ANOVA) and analysis of covariance (ANCOVA). The Bartlett test was used to check the homogeneity of the variances, with logarithmic transformations being performed when necessary. Multiple comparisons were carried out with the least significant differences (LSD) multiple range test (Snedecor \& Cochran 1980, Zar 1984).

\section{RESULTS}

\section{Expt 1}

Table 1 shows the mean values for size parameters ( $\mathrm{L}, \mathrm{DW}, \mathrm{OW}$ and VW) of the mussels used in this experiment, and Table 2 those for physiological variables (CR, IR, OIR, IRs and AE). These data showed a clear increment of the feeding variables with the size of mussels (except AE and IRs), which were found to be

Table 1. Expt 1. Mean values for length (L), dry weight (DW) and organic weight (OW) of the soft tissues, and valve weight (VW) in mussels of varying lengths ( $S$, small; $M$, medium-sized; LA, large) of the different parameters analysed. The data correspond to the mean values $\pm S E(n=5)$

\begin{tabular}{|ccccc|}
\hline & $\begin{array}{c}\mathrm{L} \\
(\mathrm{mm})\end{array}$ & $\begin{array}{c}\text { DW } \\
(\mathrm{g})\end{array}$ & $\begin{array}{c}\text { OW } \\
(\mathrm{g})\end{array}$ & $\begin{array}{c}\text { VW } \\
(\mathrm{g})\end{array}$ \\
\hline $\mathrm{S}$ & $61.60 \pm 0.96$ & $1.026 \pm 0.344$ & $0.312 \pm 0.049$ & $7.811 \pm 1.029$ \\
$\mathrm{M}$ & $73.00 \pm 1.12$ & $1.834 \pm 0.399$ & $0.458 \pm 0.084$ & $11.309 \pm 0.800$ \\
$\mathrm{LA}$ & $88.90 \pm 1.24$ & $3.762 \pm 1.016$ & $1.058 \pm 0.441$ & $19.644 \pm 2.542$ \\
\hline
\end{tabular}


Table 2. Expt 1. Mean values of the clearance rate (CR), seston ingestion rate (IR), organic matter ingestion rate (OIR), ingestion rate of total particulate matter per $g$ of mussel soft tissue dry weight $\left(\mathrm{IR}_{\mathrm{s}}\right)$ and absorption efficiency (AE) in mussels of varying lengths ( $S$, small; $M$, medium-sized; LA, large), and significance of the ANOVAs of the different parameters analysed. The data correspond to the mean values $\pm \operatorname{SE}(n=5)$

\begin{tabular}{|lccccc|}
\hline & $\begin{array}{c}\mathrm{CR} \\
\left(\mathrm{h} \mathrm{h}^{-1}\right)\end{array}$ & $\begin{array}{c}\mathrm{IR} \\
\left(\mathrm{mg} \mathrm{h}^{-1}\right)\end{array}$ & $\begin{array}{c}\text { OIR } \\
\left(\mathrm{mg} \mathrm{h}^{-1}\right)\end{array}$ & $\begin{array}{c}\mathrm{IR}_{\mathrm{s}} \\
\left(\mathrm{mg} \mathrm{h}^{-1} \mathrm{~g}^{-1}\right)\end{array}$ & $\begin{array}{c}\mathrm{AE} \\
(\%)\end{array}$ \\
\hline $\mathrm{S}$ & $2.051 \pm 0.250$ & $2.256 \pm 0.275$ & $2.060 \pm 0.250$ & $2.199 \pm 0.268$ & $88.34 \pm 0.58$ \\
$\mathrm{M}$ & $4.159 \pm 0.321$ & $4.575 \pm 0.353$ & $4.177 \pm 0.320$ & $2.495 \pm 0.193$ & $88.21 \pm 0.38$ \\
LA & $5.634 \pm 0.390$ & $6.197 \pm 0.429$ & $5.658 \pm 0.392$ & $1.647 \pm 0.114$ & $75.49 \pm 4.53$ \\
F-ratio & 9.327 & 9.327 & 9.327 & 1.526 & 7.667 \\
Significance level & $<0.01$ & $<0.01$ & 2,12 & 2,12 & $<0.01$ \\
df & 2,12 & 2,12 & & & 2,12 \\
\hline
\end{tabular}

statistically significant when testing for differences between mean values of $C R$, IR and OIR for the 3 groups of mussels (ANOVA, $\mathbf{p}<0.05$ ). Differences were significant between all groups (LSD test, $\mathrm{p}<0.05$ ).

When ANOVA included the size of mussels (given as the soft-body DW) as a covariable, non-size-related differences were found to be non-significant for any of the above variables $(p>0.05)$. The same results were obtained by comparing IRs computed for different groups of mussels by ANOVA $(p>0.05)$.

The AE of the small- and medium-sized mussels were similar, whilst that of the large ones shows a noticeable decrease, its difference from the 2 former groups being statistically significant (ANOVA, $\mathrm{p}<$ $0.01_{\text {i }}$ LSD test, $p<0.05$ ). This observation points to the existence of a critical length $(\cong 88 \mathrm{~mm})$ above which $\mathrm{AE}$ declines drastically.

\section{Expt 2}

Table 3 shows the mean values for size and Table 4 those for physiological variables measured in mussels during this experiment. CR, IR and OIR increased with the size of the mussels. However, the only statistically significant differences in this case were those between the groups of small mussels and the medium-sized plus large ones (ANOVA, $\mathrm{p}<0.01$; LSD test, $\mathrm{p}<0.05$ ), dif-

Table 3. Expt 2. Mean values for length (L), soft-tissue dry weight (DW) and organic weight $(\mathrm{OW})$, and valve weight $(\mathrm{VW})$ in mussels of varying lengths $(S$, small; $M$, medium-sized; LA, large) of the different parameters analysed. The data correspond to the mean values \pm SE $(n=16)$

\begin{tabular}{|ccccc|}
\hline & $\begin{array}{c}\mathrm{L} \\
(\mathrm{mm})\end{array}$ & $\begin{array}{c}\text { DW } \\
(\mathrm{g})\end{array}$ & $\begin{array}{c}\text { OW } \\
(\mathrm{g})\end{array}$ & $\begin{array}{c}\mathrm{VW} \\
(\mathrm{g})\end{array}$ \\
\hline $\mathrm{S}$ & $60.06 \pm 0.84$ & $0.848 \pm 0.059$ & $0.653 \pm 0.05$ & $15.684 \pm 0.187$ \\
$\mathrm{M}$ & $73.50 \pm 0.77$ & $1.698 \pm 0.089$ & $1.211 \pm 0.064$ & $10.350 \pm 0.319$ \\
$\mathrm{LA}$ & $88.38 \pm 0.66$ & $2.677 \pm 0.173$ & $2.130 \pm 0.146$ & $15.946 \pm 0.418$ \\
\hline
\end{tabular}

ferences between the latter 2 groups being not statistically significant. This was probably connected with a lower range of weight in the mussels used in this experiment, coupled to the greater variability of the physiological determinations. The ANOVA for these parameters when the DW of the mussels is used as a covariable did not reveal significant differences $(p>$ $0.05)$, and neither are the differences in $I_{\mathrm{s}}$ significant (ANOVA, $p>0.05$ ).

As in Expt 1, the AE of the large mussels was significantly lower than that of the small- and medium-sized ones (ANOVA, $p<0.001$; LSD test, $p<0.05$ ), for which there were no significant differences. This consistency confirms the existence of a critical size ( $88 \mathrm{~mm})$ above which $\mathrm{AE}$ shows a noticeable decrease.

\section{Expt 3}

In accordance with the design of this experiment, the mean values for size parameters (L, DW, OW and VW) were significantly different between size groups (small-vs medium-sized; ANOVA, $p<0.001$; LSD test, $p<0.05)$, whilst there were no significant differences between age groups (juvenile vs old; LSD test, $p>$ 0.05) (Table 5).

As in the previous experiments, there were significant differences in $\mathrm{CR}$, IR and OIR of different sized mussels (ANOVA, $p<0.001 ;$ LSD test, $\mathrm{p}<0.05)$. However, neither the ANOVA of these variables when DW was used as a covariable $(p>0.05)$ nor that of the $I_{s}(A N O V A, p>0.05$ ) showed any significant differences (Table 6).

As for the AE, the small-old mussels was the only group that showed any statistically significant difference (ANOVA, $\mathrm{p}<0.001$; LSD test, $\mathrm{p}<$ $0.05)$. The mean $A E$ for this group is 
Table 4. Expt 2. Mean values of the clearance rate (CR), seston ingestion rate (IR), organic matter ingestion rate (OIR), ingestion rate of seston per $g$ of mussel soft-tissue dry weight $\left(I_{s}\right)$ and absorption efficiency (AE) in mussels of varying lengths ( $S$, small; $\mathrm{M}$, medium-sized; LA, large), and significance of the ANOVAs of the different parameters analysed. The data correspond to the mean values $\pm \mathrm{SE}(\mathrm{n}=16)$

\begin{tabular}{|lccccc|}
\hline & $\begin{array}{c}\mathrm{CR} \\
\left(1 \mathrm{~h}^{-1}\right)\end{array}$ & $\begin{array}{c}\mathrm{IR} \\
\left(\mathrm{mg} \mathrm{h} \mathbf{~}^{-1}\right)\end{array}$ & $\begin{array}{c}\text { OIR } \\
\left(\mathrm{mg} \mathrm{h}^{-1}\right)\end{array}$ & $\begin{array}{c}\text { IR } \\
\left(\mathrm{mg} \mathrm{h}^{-1} \mathrm{~g}^{-1}\right)\end{array}$ \\
\hline $\mathrm{S}$ & $3.611 \pm 0.594$ & $2.051 \pm 0.327$ & $1.417 \pm 0.232$ & $2.545 \pm 0.438$ & $80.21 \pm 0.53$ \\
$\mathrm{M}$ & $6.931 \pm 0.841$ & $3.936 \pm 0.479$ & $2.720 \pm 331$ & $2.281 \pm 0.268$ & $81.59 \pm 0.74$ \\
LA & $9.406 \pm 1.750$ & $5.343 \pm 0.994$ & $3.691 \pm 0.687$ & $1.910 \pm 0.298$ & $70.80 \pm 2.34$ \\
F-ratio & 6.437 & 6.437 & 6.437 & 0.839 & 8.511 \\
Significance level & $<0.01$ & $<0.01$ & $<0.01$ & 2,05 & $<0.001$ \\
df & 2,45 & 2,45 & 2,45 & 2,45 & 2,45 \\
\hline
\end{tabular}

Table 5. Expt 3. Mean values of length (L), soft-tissue dry weight (DW) and organic weight (OW), and valve weight (VW) of mussels of different sizes and ages ( $\mathrm{Sj}$, small juvenile; So, small old; $\mathrm{Mj}$, medium juvenile; $\mathrm{Mo}$, medium old). Significance of the ANOVAs of the different parameters analyzed and LSD multiple range test. The data correspond to the mean values \pm SE $(n=14)$

\begin{tabular}{|lccccc}
\hline & $\begin{array}{c}\mathrm{L} \\
(\mathrm{mm})\end{array}$ & $\begin{array}{c}\text { DW } \\
(\mathrm{g})\end{array}$ & $\begin{array}{c}\text { OW } \\
(\mathrm{g})\end{array}$ & $\begin{array}{c}\text { VW } \\
(\mathrm{g})\end{array}$ & $\begin{array}{c}\text { Homogeneous } \\
\text { groups }\end{array}$ \\
\hline $\mathrm{Sj}$ & $52.9 \pm 0.9$ & $0.562 \pm 0.029$ & $0.428 \pm 0.024$ & $3.679 \pm 0.218$ & $\times$ \\
So & $55.7 \pm 0.9$ & $0.618 \pm 0.035$ & $0.470 \pm 0.029$ & $4.496 \pm 0.218$ & $\times$ \\
$\mathrm{Mj}$ & $80.6 \pm 0.8$ & $1.327 \pm 0.047$ & $1.075 \pm 0.038$ & $10.217 \pm 0.328$ & $\times$ \\
Mo & $78.8 \pm 0.8$ & $1.314 \pm 0.068$ & $1.009 \pm 0.052$ & $10.970 \pm 0.461$ & 124.31 \\
F-ratio & 76.07 & 78.85 & 83.07 & $<0.001$ \\
Significance level & $<0.001$ & $<0.001$ & $<0.001$ & 3,52 \\
df & 3.52 & 3,52 & 3.52 & & $\times$ \\
\hline
\end{tabular}

Table 6. Expt 3. Mean values of the clearance rate (CR), seston ingestion rate (IR), organic matter ingestion rate (OIR), total particulate matter ingestion rate per $g$ of mussel soft-tissue dry weight $\left(\mathrm{IR}_{\mathrm{s}}\right.$ ) and absorption efficiency (AE) of mussels of different sizes and ages ( $\mathrm{Sj}$, small juvenile; So, small old; $\mathrm{Mj}$, medium juvenile; Mo, medium old). Significance of the ANOVAs of the different parameters analysed and LSD multiple range test. The data correspond to mean values \pm SE $(n=14)$

\begin{tabular}{|lccccc|}
\hline & $\begin{array}{c}\mathrm{CR} \\
\left(\mathrm{h} \mathrm{h}^{-1}\right)\end{array}$ & $\begin{array}{c}\mathrm{IR} \\
\left(\mathrm{mg} \mathrm{h}^{-1}\right)\end{array}$ & $\begin{array}{c}\text { OIR } \\
\left(\mathrm{mg} \mathrm{h}^{-1}\right)\end{array}$ & $\begin{array}{c}\mathrm{IR}_{\mathrm{s}} \\
\left(\mathrm{mg} \mathrm{h}^{-1} \mathrm{~g}^{-1}\right)\end{array}$ \\
\hline $\mathrm{Sj}$ & $2.283 \pm 0.224$ & $2.299 \pm 0.225$ & $0.759 \pm 0.074$ & $4.171 \pm 0.407$ & $55.950 \pm 2.478$ \\
$\mathrm{So}$ & $2.248 \pm 0.286$ & $2.264 \pm 0.288$ & $0.747 \pm 0.095$ & $3.816 \pm 0.620$ & $45.533 \pm 2.127$ \\
$\mathrm{Mj}$ & $4.032 \pm 0.533$ & $4.061 \pm 0.537$ & $1.334 \pm 0.177$ & $3.051 \pm 0.409$ & $51.941 \pm 2.238$ \\
Mo & $4.154 \pm 0.577$ & $4.183 \pm 0.581$ & $1.380 \pm 0.192$ & $3.363 \pm 0.521$ & $54.152 \pm 2.061$ \\
$F$-ratio & 5.960 & 5.960 & 5.960 & 0.984 & 5.684 \\
Significance level & $<0.001$ & $<0.001$ & $<0.001$ & $>0.05$ & $<0.001$ \\
df & 3,52 & 3,52 & 3,52 & 3,52 & 3,52 \\
\hline
\end{tabular}

lower than for the other groups measured in this experiment (Table 6), which to some extent would provide a reasonable explanation for their small size in relation to age.

\section{Ingestion versus size}

As previously described, ingestion by mussels has a direct bearing on their size, and therefore the heaviest mussels (which are also the longest) are those that ingest a greater amount of food. Thus, the ingestion rate of mussels can be related to size through regression lines. Table 7 shows these regression equations computed from ingestion data obtained with natural food only (Expts 2 and 3).

If the mean values of AE for the small- and medium-sized mussels in all 3 experiments are compared to the organic content of the food ingested (OC), we can see that $A E$ increases in direct proportion to OC, following an asymptotic tendency (Fig. 1). On fitting this to the model put forward by Navarro et al. (1991), the following equation is obtained (values \pm $\mathrm{SE}_{\text {; }} \mathrm{r}=0.873$ ): 
Table 7. Parameters of the regression lines of the total particulate matter ingestion rate (IR, $\mathrm{mg} \mathrm{h}^{-1}$ ) and mass-specific ingestion rate $\left(\mathrm{IR}_{\mathrm{s}}, \mathrm{mg} \mathrm{h}^{-1} \mathrm{~g}^{-1}\right.$ ) on the body size of Mytilus edulis (DW, $\mathrm{g}$ of dry soft tissue; $\mathrm{L}, \mathrm{mm}$ ). $a$ and $b$ are fitted parameters in the allometric equation $y=a X^{b} ; \mathrm{r}$ is the correlation coefficient; $\mathrm{IR}_{\mathrm{s}}=\mathrm{IR} \times \mathrm{DW}^{-1} ; \mathrm{n}=10$ (the values are the mean of between 5 and 16 measurements)

\begin{tabular}{|c|c|c|c|c|c|c|}
\hline & Parameter & Estimate & $\mathrm{SE}$ & $T$ value & $\mathrm{p}$ & $\mathrm{r}$ \\
\hline \multirow[t]{2}{*}{ IR vs $L$} & $a$ & 0.001 & 0.000 & -7.435 & 0.0001 & 0.952 \\
\hline & $b$ & 1.970 & 0.225 & 8.751 & 0.0000 & \\
\hline \multirow[t]{2}{*}{ IR vs DW } & $a$ & 2.960 & 0.520 & 20.851 & 0.0000 & 0.934 \\
\hline & $b$ & 0.599 & 0.081 & 7.385 & 0.0001 & \\
\hline \multirow[t]{2}{*}{ IRs vs DW } & $a$ & 2.960 & 0.520 & 20.851 & 0.0000 & 0.868 \\
\hline & $b$ & -0.401 & 0.081 & -4.949 & 0.0011 & \\
\hline
\end{tabular}

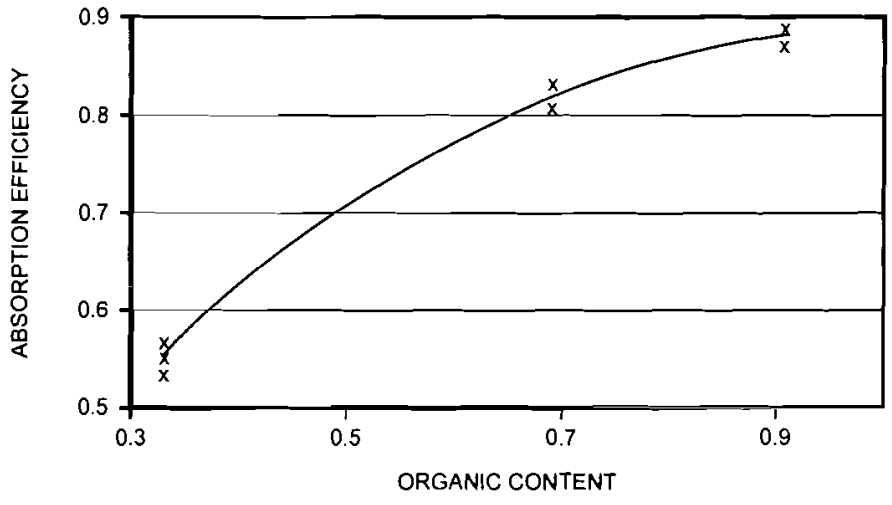

Fig. 1. Absorption efficiency as a function of the proportional organic content of the ration. The line was fitted by eye

$$
\mathrm{AE}=0.919 \pm 0.188\left(1-\mathrm{e}^{-2.784 \pm 2.814(\mathrm{OC}-0.030 \pm 0.214)}\right)
$$

where the exponential coefficients are not statistically significant. An improved fit is obtained if the $\mathrm{AE}$ is related to $1 / \mathrm{OC}$ along a linear regression (values $\pm \mathrm{SE}_{\mathrm{i}}$ $\mathrm{r}=-0.940$ ):

$$
\mathrm{AE}=1.015 \pm 0.045-0.163 \pm 0.021(1 / \mathrm{OC})
$$

In addition to a better description of data in statistical terms, the hyperbolic function also corresponds to theoretical expectations (see Navarro et. al. 1991).

\section{Respiration}

The oxygen consumption rates $\left(\mathrm{VO}_{2}\right)$ of the mussels from Expts 2 and 3 are shown in Table 8 . In both these experiments, which were performed at temperatures of 17 to $19^{\circ} \mathrm{C}$, the $\mathrm{VO}_{2}$ increases with the weight (and length) of the mussels, with differences between the values of $\mathrm{VO}_{2}$ for the different mussel groups being highly significant ( $p>0.001$ ) when compared by ANOVA. The LSD test also showed significant differences ( $p>0.05$ ) among all the size groups in both Expts 2 and 3.
When the regression of $\mathrm{VO}_{2}$ over the $\mathrm{DW}$ of the soft tissues of the mussels $\left(\mathrm{VO}_{2}=a \mathrm{DW}^{b}\right)$ is estimated for data obtained in these 2 experiments, it can be seen that, in both cases, DW accounts for over $84 \%$ of the variation in $\mathrm{VO}_{2}$ (Table 9). The values of the slopes and the intercepts of the 2 equations are very much alike, and no significant differences appeared when they were compared by means of an ANCOVA.

\section{DISCUSSION}

\section{Clearance and ingestion rates}

The relation between ingestion rates and body. size in mussels (and other filter-feeders) has been broadly discussed in previous publications (e.g. Walne 1972, Winter 1978, Bayne \& Hawkins 1990). In general terms it can be said that the amount of organic material ingested increases allometrically with the size of mussels (dry-tissue weight), with a value of $b<1$ (Winter 1973, 1978, Navarro \& Winter 1982). Our results on the whole agree with those of the above-mentioned studies (see Table 7), and the slopes of the regression lines of ingestion (expressed as IR or as mass-specific IR) on dry-tissue weight are very similar to those reported by Navarro \& Winter (1982) for Mytilus chilensis ( -0.43 and between 0.38 and 0.42 respectively in the first case, and 0.62 and between 0.58 and 0.62 in the second).

As a general rule, clearance and ingestion rates will increase rapidly as the concentration of particles increases until the ingestion rate reaches a maximum. After this point, the clearance rate declines whilst the ingestion rate remains constant until the whole digestive apparatus collapses at a very high concentration of particles, and then the ingestion rate drops considerably (Winter 1978, Riisgård \& Randløv 1981, Bayne $\&$ Hawkins 1990). Our experiments provide clear evidence of this regulation since the ingestion rates of mussels of similar size are also very similar (Tables 1 
Table 8. Oxygen consumption rates per individual $\left(\mathrm{VO}_{2}\right)$ and per mg soft-tissue dry weight $\left(\mathrm{VO}_{\mathrm{s}}\right)$ of the mussels in Expts $2(\mathrm{~L}$, large; $\mathrm{M}$, medium; $\mathrm{S}$, small) and 3 (Sj, small juvenile; So, small old; $\mathrm{Mj}$, medium juvenile; Mo, medium old). Means ( $\mathrm{n}=16$ ) $\pm \mathrm{SE}$. Relationship of homogeneous groups within each experiment according to the LSD multiple range test. Temperature: 17 to $19^{\circ} \mathrm{C}$

\begin{tabular}{|c|c|c|c|c|c|c|c|}
\hline Expt: & 2 & 2 & 2 & 3 & 3 & 3 & 3 \\
\hline Mussel: & $\mathrm{S}$ & M & L & $\mathrm{Sj}$ & So & $\mathrm{Mj}$ & Mo \\
\hline $\begin{array}{l}\text { Dry flesh } \\
\text { weight }(\mathrm{g})\end{array}$ & $\begin{array}{c}0.727 \pm \\
0.105\end{array}$ & $\begin{array}{c}1.524 \pm \\
0.727\end{array}$ & $\begin{array}{c}2.546 \pm \\
0.106\end{array}$ & $\begin{array}{c}1.261 \pm \\
0.073\end{array}$ & $\begin{array}{c}0.895 \pm \\
0.048\end{array}$ & $\begin{array}{c}2.601 \pm \\
0.137\end{array}$ & $\begin{array}{c}2.492 \pm \\
0.247\end{array}$ \\
\hline $\begin{array}{l}\mathrm{VO}_{2} \\
\left(\mathrm{ml} \mathrm{h}^{-1}\right)\end{array}$ & $\begin{array}{c}0.482 \pm \\
0.015\end{array}$ & $\begin{array}{c}0.832 \pm \\
0.056\end{array}$ & $\begin{array}{c}1.168 \pm \\
0.092\end{array}$ & $\begin{array}{c}0.696 \pm \\
0.042\end{array}$ & $\begin{array}{c}0.581 \pm \\
0.040\end{array}$ & $\begin{array}{c}1.059 \pm \\
0.053\end{array}$ & $\begin{array}{c}1.320 \pm \\
0.093\end{array}$ \\
\hline $\begin{array}{l}\mathrm{VO}_{\mathrm{s}} \\
\left(\mathrm{ml} \mathrm{h}^{-1} \mathrm{~g}^{-1}\right)\end{array}$ & $\begin{array}{c}0.680 \pm \\
0.045\end{array}$ & $\begin{array}{c}0.561 \pm \\
0.060\end{array}$ & $\begin{array}{c}0.454 . \pm \\
0.023\end{array}$ & $\begin{array}{l}0.564 \pm \\
0.044\end{array}$ & $\begin{array}{c}0.647 \pm \\
0.017\end{array}$ & $\begin{array}{c}0.409 \pm \\
0.013\end{array}$ & $\begin{array}{c}0.547 \pm \\
0.030\end{array}$ \\
\hline $\begin{array}{l}\text { Homogeneous } \\
\text { groups }\left(\mathrm{VO}_{2}\right)\end{array}$ & $x$ & $x$ & $x$ & $x$ & $x$ & $x$ & $x$ \\
\hline
\end{tabular}

Table 9. Parameters of the regression line of the oxygen consumption rate $\left(\mathrm{ml} \mathrm{h}^{-1}\right)$ versus soft-tissue dry weight ( $\mathrm{g}$ dry flesh weight) of the mussels in Expts 2 and $3(\mathrm{jm}=10$ mo old mussels, om $=20$ mo old mussels). $a$ and $b$ are fitted parameters in the allometric equation $y=a X^{b} ; r$ is the correlation coefficient

\begin{tabular}{|lccccccc|}
\hline & $\begin{array}{c}\text { Range of dry } \\
\text { flesh weight }\end{array}$ & $\begin{array}{c}\text { Temp. } \\
\left({ }^{\circ} \mathrm{C}\right)\end{array}$ & $\begin{array}{c}\text { Number of } \\
\text { observations }\end{array}$ & $a$ & $b$ & $\mathrm{p}$ \\
\hline Expt 2 & $0.80-2.68$ & $18-19$ & 18 & $0.329 \pm 0.045$ & $0.647 \pm 0.070$ & 0.917 & $<0.001$ \\
Expt 3 & $0.90-2.60$ & $18-19$ & 32 & $0.325 \pm 0.037$ & $0.690 \pm 0.054$ & 0.918 & $<0.001$ \\
Expts 2 and 3 & $0.56-2.68$ & $18-19$ & 50 & $0.328 \pm 0.028$ & $0.674 \pm 0.042$ & 0.918 & $<0.001$ \\
Expt 3 (jm) & $1.26-2.60$ & $18-19$ & 16 & $0.319 \pm 0.049$ & $0.569 \pm 0.085$ & 0.874 & $<0.001$ \\
Expt 3 (om) & $0.90-2.49$ & $18-19$ & 16 & $0.347 \pm 0.028$ & $0.803 \pm 0.047$ & 0.977 & $<0.001$ \\
\hline
\end{tabular}

to 6). These results are even more significant if one takes into account the differences between the mussels used in the experiments (mussels of varying length and age), the different composition of food used (cultured phytoplankton and natural seston), and the different experimental conditions (laboratory and raft).

The concentration of particulate material in our experiments (from 0.5 to $1 \mathrm{mg} \mathrm{l}^{-1}$ ) falls within the normal range for the Galician rías (Navarro et al. 1991) but is below values reported for other estuaries sustaining actively growing populations of mussels (Smaal et al. 1986, Bayne et al. 1993), and well below the threshold for the production of pseudo-faeces ( $3 \mathrm{mg} \mathrm{l}^{-1}$, Bayne et al. 1993). Under these conditions, and in the absence of pre-ingestive selection that could increase the organic fraction of ingested food (Bayne et al. 1993), the regulation of the ingestion rate is based on TPM rather than organic material. A comparison of the results of Expts 1, 2 and 3 (Tables 2, 4 \& 6) shows this to be the case, with similar $I_{\mathrm{s}}$ for mussels of similar length, whilst the ingestion rates of organic material vary widely and are directly proportional to the organic content of the material.

\section{Absorption efficiency}

Not much information is available regarding the

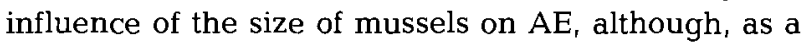
general rule, $A E$ appears to be size independent in Mytilus edulis (Vahl 1973), Mytilus chilensis (Navarro \& Winter 1982) and Modiolus modiolus (Winter 1978). The results of Expts 1 and 2 in our study, performed with different food concentrations $(1.01 \mathrm{mg}$ and

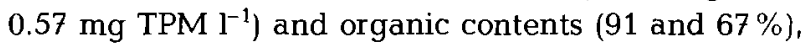
clearly show a noticeable decrease of AE in mussels reaching a length of $85 \mathrm{~mm}$. This does not necessarily mean that there is a contradiction with the above mentioned findings, since the specimens used in their experiments were well below the critical length of $85 \mathrm{~mm}$, above which the 'ageing' of the mussel becomes evident. Below this length the AE remains constant, regardless of the age and length of the mussels, with the exception of the small old mussels in Expt 3 , whose reduced AE might well account for their low growth rates.

In Mytilus fed on concentrations of seston below the threshold level for the production of pseudo-faeces, the AE rises asymptotically with the increase in food qual- 
ity (Navarro et al. 1991) according to a function which in theory would be hyperbolic, and which can be transformed into a linear regression by means of the inverse transformation of the independent variable (Navarro et al. 1996). Our experimental data fit these theoretical expectations, as the hyperbolic model accounts for $97 \%$ of the variance in $\mathrm{AE}$ as being dependent on the quality of ingested food $(r=0.940)$. The equations in Table 8 allow us to estimate the theoretical maximum value for $A E$, which would be 0.889 for $100 \%$ OC. Similarly, the $O C$ below which AE would be negative is 0.160 , which in terms of quality expressed as POM per unit of particulate volume would be 0.22 . These values resemble those previously estimated by Navarro et al. (1991) for mussels from the Ría de Arousa.

\section{Oxygen consumption rate}

Oxygen consumption is a good measure of metabolic demands for activity in bivalves (Winter 1978). However, differences in $\mathrm{VO}_{2}$ associated with variable feeding conditions are not expected to be important since the metabolic cost of feeding and digestion represents a minor component of the overall metabolic rate (Bayne et al. 1989, Widdows \& Hawkins 1989, Navarro et al. 1991). The main variation in oxygen consumption rates is accounted for by an allometric dependence on body size given by the equation $y=a x^{b}$. Although $b$ values reported in the literature are very variable, in our experiments the mean slope of this equation is 0.67 , which is close to the arithmetic mean calculated by Bayne et al. (1976) using values of the slope estimated by several different authors $(b=0.71)$.

In addition to this, a detailed examination of values from Expt 3 (Table 8) would suggest that the mass-specific $\mathrm{VO}_{2}$ of young mussels is lower than that of old mussels of the same length. In fact, if the mussels used in this experiment are divided into 2 age groups ('young' and 'old' mussels), the ANCOVA applied to $\mathrm{VO}_{2}$ data using $\mathrm{DW}$ as a covariable results in significant differences between both groups (Table 10). This demonstrates that there is a clear ageing effect which is evident irrespective of the size of the mussel, causing the mass-specific $\mathrm{VO}_{2}$ to increase with age. The consistency of these data is supported by the similarity between the $\mathrm{VO}_{2}$ of the 'old' mussels in Expt 3 and that of the mussels of the same length in Expt 2, which were also of approximately the same age (Table 8 ). On the other hand, if the groups are established according to the length of the mussels, without taking age into account, then the ANCOVA with DW as a covariable does not show any significant differences (Table 10). The increase in oxygen consumption with age is clearly illustrated in Table 9, which shows that the slope for the regressions between oxygen consumption and soft-tissue weight changes from 0.57 in $10 \mathrm{mo}$ old mussels to 0.80 in 22 mo old mussels and which results in greater respiration rates predicted for old mussels of the same size. This difference in oxygen consumption associated with age may well provide an explanation, if only partial, for the noticeable variation in the coefficients of equations calculated by various authors to relate oxygen consumption and body size in mussels (see Bayne et al. 1976), particularly when it is taken into account that the wide range of body sizes used necessarily implies age differences.

\section{Growth rate}

It is important here to point out that even if an ageing effect has been described which may account for the decline of the growth rate in mussels of greater body size or age neither the variations between the different body sizes and efficienciess nor the regulatory processes discussed herein are sufficient (except for small-old mussels, whose AE was noticeably lower than for large mussels) to account for the differences in growth between cultivated mussels of the same age, at least under the same environmental conditions. An alternative explanation for this phenomenon may be found in the limitations of food and space (see Fréchette \& Lefaivre 1990). that arise from the high density of mussels in the culture system, resulting in a limitation of ingestion rates, for both the whole raft and the individual cultivation ropes.

In the case of Galicia, the rafts are located in areas that are characterised by a low concentration of particulate matter, which nevertheless has a high organic content (between 0.5 and $1 \mathrm{mg} \mathrm{POM} \mathrm{l}^{-1}$ and $50 \%$ OC: Pérez Camacho et al. 1991, Navarro et al. 1991, this study). The reduction in particle concentration in the water flowing past the raft (as high as $50 \%$, Pérez Camacho et al. 1991) and the decrease in ingestion

Table 10. ANCOVA of the oxygen consumption rate $\left(\mathrm{ml} \mathrm{h}^{-1}\right)$ of mussels of different sizes and ages in the Expt 3 (covariate $=\mathrm{DW}, \mathrm{g}$ dry flesh weight)

\begin{tabular}{|lccc|}
\hline Factor & F-ratio & $\begin{array}{c}\text { Significance } \\
\text { level }\end{array}$ & df \\
\hline Length & & & \\
Covariate: DW & 21.560 & 0.0001 & $1,1,29$ \\
Principal effect & 1.045 & 0.3151 & \\
Age & & & $1,1,29$ \\
Covariate: DW & 183.341 & 0.0000 & \\
Principal effect & 12.097 & 0.0016 & \\
\hline
\end{tabular}


rate in mussels when the concentration of TPM drops below $0.4 \mathrm{mg} \mathrm{l}^{-1}$ (Riisgård \& Randløv 1981) may mean that, at least at those times of the year when the proportion of seston in the water is at its lowest and in spite of the regulation mechanism, the ingestion rates of the mussels would be noticeably lower at the back of a raft than at the front, leading to a clearly inferior growth rate in the former (a fact widely borne out through the experience of the mussel growers).

In very much the same way the high density of mus sels on the cultivation ropes (between 400 and 500 mussels $\mathrm{m}^{-1}$ ) means that they are superimposed on each other in several layers, with the subsequent competition for food between mussels on the same string. and a reduced availability of seston for those mussels that form the inner layers. If, in addition, we also consider the probable decrease in filtration and ingestion rates due to the reduced opening of the valves caused by the pressure that the mussels exert on each other (Jørgensen et al. 1986), the differences in growth rates between mussels with a common origin and of the same age, cultivated on the same rope, would easily be explained.

Acknowledgements. We are grateful to Daisy Arroyo, Gustavo Riestra, Jaime F. Ferreira, José L. Ortiz, Marcela Pascual, Zaul García Esquivel and crew of RV 'J. M. Navaz' for help during the field measurements. We also thank Juan Turnes for help with laboratory measurements, and Helena Regueiro and Lourdes Nieto for technical assistance. This work was supported by Project PETRI 94-0026-CO1-00 by the 'Comisión Interministerial de Ciencia y Tecnología' (ClCYT), and the 'Organización de Productores de Mejillón de Galicia' (OPMEGA).

\section{LITERATURE CITED}

Bayne BL, Hawkins AJS (1990) Filter-feeding in bivalve molluscs: control on energy balance. In: Mellinger J, Truchot JP, Lahlou B (eds) Animal nutrition and transport processes. No. 1. Nutrition in wild and domestic animals. Karger, Basel, p 70-83

Bayne BL, Thompson RJ, Widdow J (1976) Physiology: I. In: Bayne BL (ed) Marine mussels: their ecology and physiology. University Press, Cambridge, p 121-206

Bayne BL, Hawkins AJS, Navarro E, Iglesias JIP (1989) Effects of seston concentration on feeding, digestion and growth in the mussel Mytilus edulis. Mar Ecol Prog Ser $55: 47-54$

Bayne BL, Iglesias JIP, Hawkins AJS, Navarro E, Heral M, Deslous-Paoli JM (1993) Feeding behaviour of the mussel, Mytilus edulis: responses to variations in quantity and organic content of the seston. J Mar Biol Assoc UK 73: $813-829$

Conover R (1966) Assimilation of organic matter by zooplankton. Limnol Oceanogr 11:338-354

Foster-Smith RL (1975) The effect of concentration of suspension on the filtration rates and pseudofecal production for Mytilus edulis L., Cerastoderma edule L. and Venerupis pullastra (Montagu). J Exp Mar Biol Ecol 17:1-22
Fréchette M, Lefaivre D (1990) Discriminating between food and space limitation in benthic suspension feeders using self-thinning relationships. Mar Ecol Prog Ser 65:15-23

Griffiths CL (1980) Filtration, respiration and assimilation in the black mussel Choromytilus meridionalis. Mar Ecol Prog Ser 3:63-70

Griffiths CL, King JA (1979) Some relationships between size, food availability and energy balance in the ribbed mussel Aulacomya ater. Mar Biol 51:141-149

Iglesias JIP, Pérez Camacho A, Navarro E, Labarta U, Beiras R, Hawkins AJS, Widdows J (1996) Microgeographic variability, absorption and condition of mussels (Mytilus galloprovincialis LMK.): a transplant experiment. J Shellfish Res 3:673-680

Jørgensen CB, Mølenberg F, Sten-Knudsen O (1986) Nature of the relation between ventilation and oxygen consumption in filter feeders. Mar Ecol Prog Ser 29:73-88

Navarro E, Iglesias JIP, Pérez Camacho A, Labarta U, Beiras R (1991) The physiological energetics of mussels (Mytilus galloprovincialis Lmk) from different cultivation rafts in the Ría de Arosa (Galicia, N.W. Spain). Aquaculture 94: 197-212

Navarro E, lglesias JIP, Pérez Camacho A, Labarta U (1996) The effect of diets of phytoplankton and suspended bottom material on feeding an absorption of raft (Mytilus galloprovincialis Lmk). J Exp Mar Biol Ecol 198:175-189

Navarro JM, Winter JE (1982) Ingestion rate, assimilation efficiency and energy balance in Mytilus chilensis in relation to body size and different algal concentration. Mar Biol 67:255-266

Pérez Camacho A, González R, Fuentes J (1991) Mussel culture in Galicia (N.W. Spain). Aquaculture 94:263-278

Pérez Camacho A, Villaba A, Beiras R, Labarta U (1997) Absorption efficiency and condition of cultured mussels (Mytilus edulis galloprovincialis Linnaeus) of Galicia (NW Spain) infected by parasites Marteilia refringens Grizel et al. and Mytilicola intestinalis Steuer. J Shellfish Res 16:77-82

Riisgård HU, Randløv A (1981) Energy budgets, growth and filtration rates in Mytilus edulis at different algal concentration. Mar Biol 61:227-234

Smaal AC, Verhagen JHG, Coosen J, Haas HA (1986) lnteraction between seston quantity and quality and benthic suspension feeders in the Oosterschelde, The Netherlands. Ophelia 26:385-399

Snedecor GW, Cochran WG (1980) Statistical methods. Iowa State University Press, Ames

Tenore KR, González N (1976) Food chain patterns in the Ría de Arosa, Spain: area of intense mussel aquaculture. In: Persoone G, Jaspers E (eds) Population dynamic of marine organisms in relation with nutrient cycling in shallow waters. Proc 10th Eur Mar Biol Symp, Vol 2. Universal Press, Wettern, p 601-619

Thompson RJ, Bayne BL (1972) Active metabolism associated with feeding in the mussel Mytilus edulis L. J Exp Mar Biol Ecol 8:191-212

Thompson RJ, Bayne BL (1974) Some relationships between growth, metabolism and food in the mussel Mytilus edulis. Mar Biol 27:317-326

Vahl O (1973) Pumping and oxygen consumption rates of Mytilus edulis L. of different sizes. Ophelia 12:45-51

Walne PR (1972) The influence of current speed, body size and water temperature on the filtration rate of five species of bivalves. J Mar Biol Assoc UK 52:345-374

Widdows J (1978) Combined effects of body size, food concentration and season on the physiology of Mytilus edulis. J Mar Biol Assoc UK 58:109-124

Widdows J, Bayne BL (1971) Temperature acclimation of 
Mytilus edulis with reference to its energy budget. J Mar Biol Assoc UK 51:827-843

Widdows J, Hawkins AJS (1989) Partitioning of rate of heat dissipation by Mytilus edulis into maintenance, feeding and growth components. Physiol Zool 62:764-784

Widdows J, Fieth P, Worral CM (1979) Relationship between seston, available food and feeding activity in the common mussel Mytilus edulis. Mar Biol 50:195-207

Winter JE (1973) The filtration rate of Mytilus edulis and its

Editorial responsibility: Otto Kinne (Editor),

Oldendorf/Luhe, Germany dependence on algal concentration, measured by a continuous automatic recording apparatus. Mar Biol 22: $317-328$

Winter JE (1978) A review of the knowledge of suspensionfeeding in lamellibranchiate bivalves, with special reference to artificial aquaculture systems. Aquaculture 13: $1-33$

Zar JH (1984) Biostatistical analysis. Prentice Hall, Englewood Cliffs, NJ

Submitted: June 4, 1999; Accepted: January 27, 2000 Proofs received from author(s): June 5, 2000 